\title{
Investigation of the effectiveness of algan hemostatic agent in bleeding control using an experimental partial splenectomy model in rats
}

\author{
Deneysel parsiyel splenektomi modelinde sıçanlarda algan hemostatik ajanın kanama \\ kontrolünde etkinliğinin araştırılması \\ Ahmet MIDI, Husamettin EKICI, Ali KUMANDAS, Omercan DURMUS, Buse BODIC, Mehmet TIRYAKI, Mehmet \\ Sabri BALIK, Erdem YESILADA
}

\begin{abstract}
Objective: Algan hemostatic agent (AHA) is a plant-based hemostatic agent produced in Turkey. Although, there is a great improvement in the hemostatic technologies, more effective hemostatic products are required to be produced. The aim of this study was to demonstrate the efficacy of AHA in a partial splenectomy model in rats. In addition, in this model, postoperative abdominal adhesion was evaluated.

Materials and Methods: In this study 5-7 weeks old 64 rats were used. Rats were randomly divided into 8 groups, each consisting of eight rats (4 groups heparinized and 4 groups nonheparinized). Experimental splenectomy was performed and the gauze impregnated with saline was applied to the control group for the hemorrhage control, the gauze impregnated with liquid AHA, gel and powder form of AHA, was applied to the experimental groups.

Results: The time to reach complete homeostasis was significantly shorter in all AHA groups compared to the control
\end{abstract}

\author{
Ahmet Midi(四) \\ Department of Pathology, School of Medicine, Bahcesehir University, \\ Kadlkoy, Istanbul, Turkey \\ e-mail:ahmetmidi@yahoo.com \\ Husamettin Ekici \\ Department of Pharmacology and Toxicology, Veterinary Faculty, \\ Kırlkkale University, Kırlkkale, Istanbul, Turkey \\ Ali Komandas \\ Department of Surgery, Veterinary Faculty, Kırlkkale University, Kırıkkale, \\ Turkey \\ Omercan Durmus, Buse Bodic \\ Third year student, School of Medicine, Bahcesehir University, Goztepe, \\ Istanbul, Turkey \\ Mehmet Tiryaki \\ Neurosurgery Clinic, Lütfi Kirdar Kartal Education and Research Hospital, \\ Kartal, Istanbul, Turkey \\ Mehmet Sabri Balik \\ Department of Orthopedics and Traumatology, School of Medicine, Recep \\ Tayyip Erdoğan University, Rize, Turkey \\ Erdem Yesilada \\ Department of Pharmacognosy and Phytotherapy, School of Pharmacy, \\ Yeditepe University, Maltepe, Istanbul, Turkey
}

Submitted / Gönderilme: 12.09.2018

Accepted/Kabul: 23.11 .2018 group. The powder and the gel forms of AHA stopped the bleeding in heparinized and non-heparinized groups in 1 second. The AHA fluid (sponge) form stopped the bleeding in the first application in the control group less than 10 seconds and the second time application was not necessary. The bleeding was able to be controlled in the heparinized control group (saline impregnated sponge) by 55 seconds and in the non-heparinized control group by 38 seconds.

Conclusion: This study showed that AHA is a highly effective hemostatic agent, which would be beneficial in controlling hemorrhage.

Keywords: Algan hemostatic agent, Hemostasis, Rat, Bleeding control, Splenectomy

ÖZ

Amaç: Algan hemostatik ajan (AHA), Türkiye'de üretilen bitki bazlı hemostatik bir maddedir. Hemostatik teknolojilerdeki büyük gelişmelere rağmen, kanamanın kontrolünde kullanılmak üzere daha etkili hemostatik ürünlerin üretilmesi gerekmektedir. $\mathrm{Bu}$ çalışmanın amacı, AHA'nın sıçanlarda parsiyel splenektomi modelindeki etkinliğini göstermektir. Ayrıca bu modelde batın yapışıklı̆g 1 değerlendirilmiştir.

Gereçler ve Yöntemler: Bu çalışmada 5-7 haftalık 64 sıçan kullanıldı. Siçanların her biri sekiz sıçandan oluşan 8 gruba ayrıldı (heparinize edilmiş 4 grup ve heparinize edilmemiş 4 grup). Deneysel splenektomi yapıldı ve kontrol grubuna hemoraji kontrolü için serum fizyolojik emdirilmiş gazlı bez uyguland1, deney gruplarına AHA sıvı emdirilmiş gazlı bez, jel ve toz formu uyguland1.

Bulgular: Komple hemostaza ulaşma süresi, tüm AHA gruplarında kontrol grubuna kıyasla anlamlı olarak daha kısa idi. AHA'nın toz ve jel formları heparinize ve heparinize olmayan gruplarda 1 saniyede kanamayı durdurdu. AHA sıvı (sünger) formu, kontrol grubunda ilk uygulamada tüm sıçanlarda kanamayı durdurdu (10 saniyenin altında). Kanama, heparinize edilmiş kontrol grubunda (serum fizyolojik emdirilmiş gazlı bez) ortalama 55 saniyede ve heparinize olmayan kontrol grubunda 38 saniyede kontrol edilebildi.

Sonuç: Bu çalışma, AHA'nın hemorajinin kontrol edilmesinde yararlı olabilecek oldukça etkili bir hemostatik ajan olduğunu göstermiştir.

Anahtar kelimeler: Algan hemostatik ajan, Hemostaz, Sıçan, Kanama kontrolü, Splenektomi. 


\section{Introduction}

The reason for many splenectomies nowadays is spleen bleeding caused as a result of elective spleen surgeries applied due to several medical reasons and especially trauma. The spleen is the second most frequently injured organ after abdominal traumas and missed splenic injury is the most frequent preventable cause of death in patients with trauma. For this reason, there are studies on partial spleen protection and in control of spleen hemorrhage following trauma [1$3]$. In the early 1900 s, the mortality rate for non-surgical treatment of splenic injuries was approximately $100 \%$. For this reason, splenectomy was widely acknowledged treatment option in spleen injuries [4].

Today, for many patients with solid organ damage, laparotomy is not necessary by virtue of imaging techniques. Since, non-surgical treatments in solid organ injuries give better results comparing to the surgical treatments, nonsurgical treatment options are highlighted. Besides, the risk of postoperative infection in splenectomy is elevated in spleen injuries, therefore the approaches protecting the spleen come to the forefront. There are many hemostatic agents available such as; bovine collagen, bovine thrombin, autologous plasma, fibrin glue [5-12], and it is necessary to decide which method to use according to the cost of the procedure, bleeding severity and personal experience. However, despite these products and major developments in medicine, an ideal product that can be used to control bleeding is not yet produced and more effective hemostatic products are necessary to be produced.

The algan hemostatic agent (AHA) is the herbal extract derived from the standardized blend of six different plants (Table I) $[13,14]$. To the best of our knowledge, it is the first and only patented product in the world, made solely of herbs, with no additives. (Patent application no: a2015 / 00018, application publication no. TR2015 0018 A2).

All biocompatibility tests such as sensitization, cytotoxicity and irritation and hemodynamic tests of the AHA had been performed, and the results supported its safety and efficacy as a hemostatic agent $[13,14]$. AHA can be easily formulated to be applied locally $[13,14]$. Further, it has low cost and does not require special storage conditions.

The aim of this study is to assess the hemostatic effect of the partial splenectomy model of the AHA. In addition, postoperative abdominal adhesion is evaluated.
Table I. Plants with algan hemostatic agent composition.

\begin{tabular}{|l|l|l|}
\hline The name of the plant & English name & Used part \\
\hline Achillea millefolium & Yarrow & Flower \\
\hline Juglans regia & Walnut & Leaf \\
\hline Lycopodium clavatum & Club moss & Whole plant \\
\hline $\begin{array}{l}\text { Rubus caesius, } \\
\text { R. fruticosus }\end{array}$ & Blackberry & Leaf \\
\hline Viscum album & European Mistletoe & Whole plant \\
\hline Vitis vinifera & Vine & Leaf \\
\hline
\end{tabular}

\section{Materials and Methods}

This study was approved by the Institutional Animal Experiments Local Ethics Committee of Kurkkkale University (number, 2018/10). All animal studies conformed to the animal experiment guidelines of the Committee for Humane Care. All animals received care in compliance with the "Principles of Laboratory Animal Care" formulated by the National Society for Medical Research and "Guide for the Care and the Use of Laboratory Animals" prepared by the US National Academy of Sciences and published by the US National Institute of Health (NIH Publications, No:80-23). The experiment was carried out as described in the literature [1].

In the study, 64 rats which are 180-210 grams and 5-7 weeks old were used. Rats were fed as ad libitum and examined under standard laboratory conditions according to a 12-hour dark-light period. Rats were randomly divided into two groups each having 32 rats as; heparinized and nonheparinized groups. Subsequently, the experimental animals were randomly divided into 8 groups each having eight rats. The heparinized group was administered intraperitoneal $640 \mathrm{IU} / \mathrm{kg}$ heparin for 3 days once a day. The other group did not receive heparin. Group 1 (Heparinized control group), Group 2 (Heparinized AHA powder group), Group 3 (Heparinized AHA gel group), Group 4 (Heparinized liquid AHA-impregnated sponge group), Group 5 (NonHeparinized control group), 6th group (Non-Heparinized AHA powder group), 7th group (Non-Heparinized AHA gel group), 8th group (Non-Heparinized AHA liquid impregnated sponge group).

\section{Operation procedure}

During the operations, all rats were treated according to the Guide for the Care and Use of Laboratory Animals. Procedures were performed under general anesthesia with ketamine hydrochloride $(100 \mathrm{mg} / \mathrm{kg})$ and xylazine hydrochloride $(10 \mathrm{mg} / \mathrm{kg})$. All efforts were made to minimize animal suffering and the number of animals used. 
The furs on the abdominal anterior wall of all rats were removed. After disinfection with povidone-iodine solution, $3 \mathrm{~cm}$ median incision was made. The spleen was located and in the lower pole of the spleen $1 \mathrm{~cm}$, partial splenectomy was performed in the rats in all groups. The duration of bleeding was evaluated according to the protocol previously explained [12]. When splenectomy bleeding had started, the bleeding area was pressed with a sponge for 10 seconds, and then the sponge was removed. Liquid AHA-impregnated sponge, and the saline-impregnated sponge were placed in this area and a light pressure was applied to the area. Bleeding was checked 10 seconds after the start of the pressure. If bleeding stopped, it was recorded as 'bleeding stopped'. If not, the procedure was repeated until the bleeding was controlled with the same amount of material. In the AHA gel and AHA powder forms, the bleeding area was left unpressed and was left open after the application. Bleeding was checked. The time at which the bleeding stopped was noted as the time of the bleeding control (Figure 1).

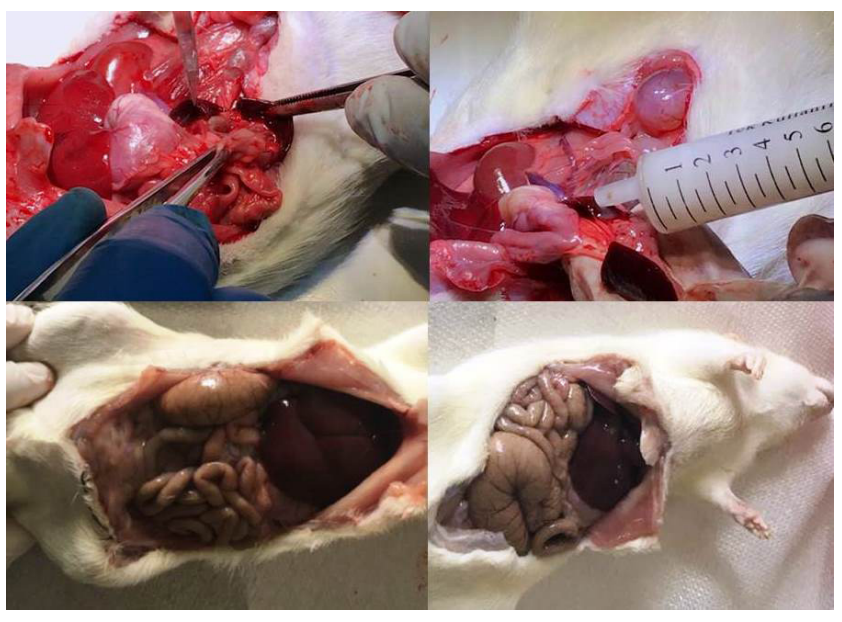

Figure 1. The images of the spleen cut from the center and the application of the AHA gel. On the postoperative 5th day, there is no adherence in the abdomen in the control and AHA liquid groups
On the 5th day of the laparotomy, the rats underwent surgical site disinfection on the anterior wall of the abdomen under anesthesia. The abdomen was opened and the intraabdominal adhesiveness quantitatively evaluated according to the Bothin scale [12]. Hematoma and fluid collection were examined in the abdomen, if it existed. The rats were sacrificed by cutting inferior vena cava.

\section{Statistical analyses}

SPSS software version 22.0 (SPSS Inc., Chicago, IL) was used to analyze the data of this study. Weight, bleeding time and adherence scores were calculated and mean values were compared among the four groups using analysis of variance (ANOVA). When differences were found, any group difference was determined by Duncan's multiple range tests. The results were assessed at a 95\% confidence interval and a suggestiveness level of $\mathrm{P}<0.05$.

\section{Results}

The shortest duration of bleeding was found in the AHA powder group. This was followed by the gel group and the liquid group. The duration of bleeding in the control group was significantly longer than in the experimental groups (Table II). There was no difference in terms of body weights between the groups. The powder and the gel forms of AHA stopped the bleeding in heparinized and non-heparinized groups in 1 second. The AHA fluid (sponge) form stopped the bleeding in the first time in control group less than 10 seconds and the second time application was not necessary.

The saline-impregnated sponge was able to control bleeding in the heparinized control group at the average of 55 seconds (min: 40-max: $70 \mathrm{sec}$ ) and in the non-heparinized

Table II. Mean bleeding time and the body weight distribution of the groups.

\begin{tabular}{|c|c|c|c|c|c|c|c|c|c|}
\hline & $\begin{array}{l}\text { Group } 1 \\
\text { (HC) }\end{array}$ & $\begin{array}{l}\text { Group } 2 \\
\text { (HP) }\end{array}$ & $\begin{array}{l}\text { Group } 3 \\
(\mathrm{HG})\end{array}$ & $\begin{array}{l}\text { Group } 4 \\
\text { (HL) }\end{array}$ & $\begin{array}{l}\text { Group } 5 \\
(\mathrm{NHC})\end{array}$ & $\begin{array}{l}\text { Group } 6 \\
\text { (NHP) }\end{array}$ & $\begin{array}{l}\text { Group } 7 \\
\text { (NHG) }\end{array}$ & $\begin{array}{l}\text { Group } 8 \\
(\mathrm{NHL})\end{array}$ & $\mathrm{P}$ \\
\hline \begin{tabular}{|l|}
$\begin{array}{l}\text { Weight } \\
\text { (gram) }\end{array}$ \\
\end{tabular} & $190.6 \pm 5.5$ & $189.5 \pm 7.3$ & $183.6 \pm 10.6$ & $194.6 \pm 5.7$ & $175.6 \pm 10.5$ & $182.4 \pm 7.5$ & $187.9 \pm 7.5$ & $184.3 \pm 9.5$ & $\mathrm{P}>0.05$ \\
\hline \begin{tabular}{|l|} 
Average \\
Bleeding \\
time, second \\
(Min-max)
\end{tabular} & $\begin{array}{l}55(40-70 \\
\text { sec.) } \\
\text { (Min-max) }\end{array}$ & $1 \mathrm{sec}$. & $1 \mathrm{sec}$. & $\begin{array}{l}<10 \mathrm{sec} \text {. (at } \\
\text { first control) }\end{array}$ & $\begin{array}{l}38 \mathrm{sec} . \\
(30-50 \mathrm{sec} .) \\
(\text { Min-max) }\end{array}$ & $1 \mathrm{sec}$. & $1 \mathrm{sec}$. & $\begin{array}{l}<10 \mathrm{sec} \text {. (at } \\
\text { first control) }\end{array}$ & $\mathrm{P}<0.001$ \\
\hline
\end{tabular}

HC: Heparinized control group, HP: Heparinized AHA powder group, HG: Heparinized AHA gel group, HL: Heparinized AHA liquid-impregnated sponge group, NHC: Non-Heparinized control group, NHP: Non-Heparinized AHA powder group, NHG: Non-Heparinized AHA gel group, NHL: NonHeparinized AHA liquid-impregnated sponge. AHA: Algan Hemostatic Agent. 
Table III. Assessment of the adhesion forms of the groups (\%)

\begin{tabular}{|c|c|c|c|c|c|c|c|c|c|}
\hline Adhesion Zone & $\begin{array}{l}\text { Group } 1 \\
(\mathrm{HC})\end{array}$ & \begin{tabular}{|l} 
Group 2 \\
(HP)
\end{tabular} & $\begin{array}{l}\text { Group } 3 \\
(\mathrm{HG})\end{array}$ & $\begin{array}{l}\text { Group } 4 \\
(\mathrm{HL})\end{array}$ & \begin{tabular}{|l} 
Group 5 \\
(NHC)
\end{tabular} & $\begin{array}{l}\text { Group } 6 \\
\text { (NHP) }\end{array}$ & \begin{tabular}{|l} 
Group 7 \\
$(\mathrm{NHG})$
\end{tabular} & $\begin{array}{l}\text { Group } 8 \\
\text { (NHL) }\end{array}$ & $\mathrm{P}$ \\
\hline Between omentum and target organ & 6 & 7 & 6 & 6 & 6 & 7 & 7 & 6 & \multirow[t]{12}{*}{$>0.05$} \\
\hline Omentum abdominal scar & 0 & 0 & 0 & 0 & 0 & 0 & 0 & 0 & \\
\hline Between omentum and other sites & 0 & 0 & 0 & 0 & 0 & 0 & 0 & 0 & \\
\hline From adnexa to target organ & 0 & 0 & 0 & 0 & 0 & 0 & 0 & 0 & \\
\hline Adnexa abdominal scar & 0 & 0 & 0 & 0 & 0 & 0 & 0 & 0 & \\
\hline From adnexa to other places & 0 & 0 & 0 & 0 & 0 & 0 & 0 & 0 & \\
\hline Adhesive tape between any two organs & 0 & 0 & 0 & 0 & 0 & 0 & 0 & 0 & \\
\hline Target organ abdominal scar & 0 & 0 & 0 & 0 & 0 & 0 & 0 & 0 & \\
\hline Target organ abdominal wall & 0 & 0 & 0 & 0 & 0 & 0 & 0 & 0 & \\
\hline Target organ intestine & 2 & 1 & 1 & 2 & 2 & 1 & 0 & 1 & \\
\hline Target organ liver & 0 & 0 & 0 & 0 & 0 & 0 & 0 & 0 & \\
\hline Adhesion in any other organ & 0 & 0 & 0 & 0 & 0 & 0 & 0 & 0 & \\
\hline Total Adhesion Score & 8 & 8 & 7 & 8 & 8 & 8 & 7 & 7 & $>0.05$ \\
\hline
\end{tabular}

HC: Heparinized control group, HP: Heparinized AHA powder group, HG: Heparinized AHA gel group, HS: Heparinized AHA liquid impregnated sponge group, NHC: Non-Heparinized control group, NHP: Non-Heparinized AHA powder group, NHG: Non-Heparinized AHA gel group, NHL: NonHeparinized AHA liquid impregnated sponge. AHA: Algan Hemostatic Agent.

control group at 38 (min: 30-max: $50 \mathrm{sec}$ ) seconds (Table II).

There was no hematoma and fluid accumulation in the abdomen on the postoperative 5th day. The lowest adhesion score was 7 and the highest was 8 . There was no difference in the adhesion scores between the control and treatment groups (Table III).

All of the applications were performed with the sterile AHA in a sterile environment. All rats in the treatment and control groups were alive on the 5th postoperative day. On the postoperative 5th day, when the abdomen was opened, no surgical infection was observed in neither control nor the AHA groups.

\section{Discussion}

All forms of the AHA have stopped bleeding in the first second in the partial splenectomy bleeding model used in this study and we have shown that they are potential candidates as an effective product in the use of hemostasis in splenic injuries or partial splenectomy operations. In heparinized and non-heparinized powder and gel groups, the bleeding was stopped within 1 second. The AHA was significantly different from the control groups in terms of bleeding control efficacy.
Several hemostatic agents have been used in the treatment of solid organ hemorrhages [15-17], and they work by different mechanisms. Tissue adhesives, cyanoacrylates are used in many clinical situations for the hemostatic purposes [18-20].

In one study in the literature, hemostatic efficacy was compared in ankaferd and fibrin glue in a rat model of partial splenectomy [21]. In this study, Fibrin Glue (Tisseel ${ }^{\circledR}$ ) was able to stop bleeding for an average of 11 seconds and Ankaferd Blood Stopper for an average of 10 seconds. As we have shown in the current study, AHA managed to stop the bleeding in as fast as 1 second.

In another study, the hemostatic effect of calcium alginate in experimental splenic injury model was investigated. In that study, a spleen laceration model was established and the hemostatic effect of calcium alginate was evaluated. Calcium alginate has been shown to reduce the intraoperative bleeding after spleen injury. When compared to the $0.9 \% \mathrm{NaCl}$ gauze and sham groups, inflammation, vascularization, and fibrosis have been found statistically higher in calcium alginate group. And the adhesion score has also been found higher in the calcium alginate group [22].

Nowadays, many products used for hemostasis have some difficulties during application such as compression. However, AHA does not require compression compared 
to the other products and it has an easy-to-apply feature, as well as an advantage over other products in terms of hemostasis in a much shorter time.

All forms of the AHA and the results of the effectiveness in hemostasis differ greatly from the other available products. Experimental conditions may vary in terms of animal weight, the experience of the practitioner, technical differences, vessel variations, laboratory conditions, and other factors affecting this disparity and the other bleeding arrestors. Therefore, all products need to be compared in the same experiment protocol to evaluate their efficacies in bleeding control.

Prevention of peritoneal adhesions is important issues in surgery. There are many agents such as phospholipase inhibitors, dextran, corticosteroids, phospholipids, and methylene blue used to prevent postoperative abdominal adhesions [23-25].

According to some studies in the literature, some of the haemostatic agents have postoperative abdominal adhesion enhancing effect. Other studies show the opposite of these results $[22,26,27]$. Our study showed that AHA did not have a positive or negative effect on postoperative intraabdominal adhesion formation.

According to the results of this study and together with the other studies in the literature, AHA is a highly effective hemostatic agent in the partial splenectomy hemorrhage model in the world, but the actual difference can only be demonstrated by comparative studies. The future studies are needed to further this study.

\section{Funding}

This study was supported by the Algan Group Health Services (Algan Group Health Services Import and Export Industry and Trade Limited Company, Istanbul, Turkey). The company provided the study materials for the scientists, but had no role for the study design, data collection and analysis. The decision to publish and the preparation of the manuscript also belong to the authors.

\section{Conflict of Interest}

We wish to confirm that there are no known conflicts of interest associated with this publication and there has been no significant financial support for this work that could have influenced its outcome.

\section{References}

1. Uranus S, Mischinger HJ, Pfeifer J, et al. Hemostatic methods for the management of spleen and liver injuries. World J Surg 1996;20:1107-11. doi: 10.1007/s002689900.

2. Davies DA, Pearl RH, Ein SH, Langer JC, Wales PW. Management of blunt splenic injury in children: Evolution of the nonoperative approach. J Pediatr Surg 2009;44:1005-8. doi: 10.1016/j.jpedsurg.2009.01.024.

3. Kuzu A, Aydıntuğ S, Karayalçın K, Köksoy C, Yerdel M A, Eraslan S. Use of autologous fibrin glue in the treatment of splenic trauma: an experimental study. Journal of Royal College of Surgeons Edinburgh 1992;37:162-4.

4. King H, Shumacker HB Jr. Splenic studies: Susceptibility to infection after splenectomy performed in $\backslash$ wiancy. Ann Surg 1952;136: 239-42.

5. Schwartz M, Madariaga J, Hirose R, et al. Comparison of a new fibrin sealant with standard topical hemostatic agents. Arch Surg 2004;139:1148-54. doi:10.1001/ archsurg.139.11.1148

6. Hanks JB, Kjaergaard HK, Hollingsbee DA. A comparison of the haemostatic effect of Vivostat patient-derived fibrin sealant with oxidised cellulose (Surgicel) in multiple surgical procedures. Eur Surg Res 2003;35:439-44. doi: 10.1159/000072229

7. Ersoy G, Kaynak MF, Yilmaz O, Rodoplu U, Maltepe F, Gokmen N. Hemostatic effects of microporous polysaccharide hemosphere in a rat model with severe femoral artery bleeding. Adv Ther 2007;24:485-92. doi: 10.1007/BF02848770

8. Ward KR, Tiba MH, Holbert WH, et al. Comparison of a new hemostatic agent to current combat hemostatic agents in a swine model of lethal extremity arterial hemorrhage. J Trauma 2007;63:276-83. doi: 10.1097/TA.0b013e3180eea8a5

9. Beyazit Y, Kurt M, Kekilli M, Goker H, Haznedaroglu IC. Evaluation of hemostatic effects of Ankaferd as an alternative medicine. Altern Med Rev 2010;15:329-36.

10. Uçar Albayrak C, Caliskan U, Haznedaroglu IC, Goker H Haemostatic actions of the folkloric medicinal plant extract Ankaferd Blood Stopper. J Int Med Res 2008;36:1447-8.doi: 10.1177/147.323.000803600121.

11. Köse R, Sogut Ö, Demir T, Koruk İ. Hemostatic efficacy of folkloric medicinal plant extract in a rat skin bleeding model. Dermatol Surg 2012;38, 760-6. doi: 10.1111/j.15244725.2011.02288.x

12. Yavuz E, Kalayci M U, Kesici S, Kesici U, Ozkara S, Yalcin O. Efficacy of ankaferd blood stopper in bleeding control in experimental partial splenectomy model. Kafkas Universitesi Veteriner Fakultesi Dergisi 2012;18: 753-8. doi:10.9775/ kvfd.2012.6324

13. Midi A, Kumandaş A, Ekici H, et al. Investigation of the effectiveness of algan hemostatic agent in renal venous bleeding model in rats. EJMI 2018; 2: 129-32. doi: 10.14744/ ejmi.2018.32032.

14. Midi A, Ozyurek H E, Karahan S, et al. Investigation of efficacy of the plant based algan hemostatic agent in hepatectomy bleeding model in rats. EJMI 2018; 2: 195-201 | doi: 10.14744/ejmi.2018.35744. 
15. Schwaitzberg SD, Chan MW, Cole DJ, et al. Comparison of poly-N-acetyl glucosamine with commercially available topical hemostats for achieving hemostasis in coagulopathic models of splenic hemorrhage. J Trauma 2004;57:S29-32. doi: 10.1097/01.TA.000.013.6747.35311.60.

16. Chan MW, Schwaitzberg SD, Demcheva M, Vournakis J, Finkielsztein S, Connolly RJ. Comparison of poly-Nacetyl glucosamine (P-GlcNAc) with absorbable collagen (Actifoam), and fibrin sealant (Bolheal) for achieving hemostasis in a swine model of splenic hemorrhage. J Trauma 2000;48:454-8.

17. Holcomb JB, McClain JM, Pusateri AE, et al. Fibrin sealant foam sprayed directly on liver injuries decreases blood loss in resuscitated rats. J Trauma 2000;49:246-50.

18. Tekin MI, Peşkircioğlu L, Boyvat F, et al. Practical approach to terminate urinary extravasation: percutaneous fistula tract embolization with $\mathrm{n}$ butyl cyanoacrylate in a case with partial nephrectomy. Tech Urol 2000;7:67-9.

19. Grummet JP, Costello AJ, Swanson LC, et al. Vesicourethral anastomosis with 2-octyl cyanoacrylate adhesive in an in vivo canine model. Urology 2001;60:935-8. doi:10.1016/ S0090-4295(02)01887-3.

20. Berrevoet F, de Hemptinne B. Clinical application of topical sealants in liver surgery: does it work? Acta Chirurgica Belgica 2007;107:504-7. doi: 10.1080/00015.458.2007.116 80111.
21. Yucel M O, Polat H, Bagcioglu M, et al. Comparison of the efficacy and histopathological effects of three hemostatic agents in a partial nephrectomy rat model. Int Urol Nephrol 2016; 48:65-71. doi:10.1007/s11255.015.1129-3.

22. Taşkın A K, Yaşar M, Özaydın İ, et al. The hemostatic effect of calcium alginate in experimental splenic injury model. Ulus Travma Acil Cerrahi Derg 2013;19:195-99. doi: 10.5505/tjtes.2013.30676.

23. Aarons CB, Cohen P A, Gower A, et al. Statins (HMG-CoA Reductase Inhibitors) decrease postoperative adhesions by increasing peritoneal fibrinolytic activity. Ann Surg 2007; 245:176-84.

24. Bae JS, Ahn S J, Yim H, et al. Prevention of intraperitoneal adhesions and abscesses by polysaccharides isolated from phellinus spp in a rat peritonitis model. Ann Surg 2005; 241: 534-40.

25. Galili Y, Ben-Abraham R, Rabau M, et al. Reduction of surgery-induced peritoneal adhesions by methylene blue. Am J Surg 1998;175:30-2.

26. Gomez NA, Iniguez SA, Leon $\mathrm{C}$ J. Use of oxidized regenerated cellulose (TC7) to prevent postoperative adhesions in laparoscopic surgery. Surg Endosc 1994; 8:934.

27. Cömert M, Karakaya K, Barut F, et al. Does intraabdominal use of Ankaferd Blood Stopper cause increased intraperitoneal adhesions? Ulus Travma Acil Cerrahi Derg 2010; 16:383-9. 